\title{
Acta
Biochimica
Polonica
}

Vol. 40 No. 4/1993

QUARTERLY

\section{Phosphorylation of acidic ribosomal proteins by ribosome- -associated protein kinases of Saccharomyces cerevisiae and Schizosaccharomyces pombe*}

\author{
Teresa Jakubowicz, Małgorzata Cytryńska, Wiktor Kowalczyk and Eugeniusz Gasior
}

Department of Molecular Biology, Institute of Microbiology, Maria Curie-Skłodowska University, 20-033 Lublin, Akademicka 19, Poland

Received 2 July, 1993

\begin{abstract}
Two proteins of $13 \mathrm{kDa}$ and $38 \mathrm{kDa}$, the components of $60 \mathrm{~S}$ ribosomal subunits, were identified as phosphorylation substrates for protein kinases tightly associated with $S$. cerevisiae and Schizosaccharomyces pombe ribosomes. An enzyme with properties of multifunctional casein kinase II was detected in ribosome preparations from both yeast species. In S. cerevisiae another protein kinase with high substrate specificity toward those proteins was also identified. By using isoelectric focusing, the protein band of $13 \mathrm{kDa}$ from $S$. cerevisiae and $S$. pombe was resolved respectively into three and four major forms of different charge. The same protein forms were phosphorylated in the in vivo ${ }^{32}$ P-labelling experiments.
\end{abstract}

The large ribosomal subunits of all eucaryotic organisms studied so far, contain a set of unusually acidic proteins of molecular mass about $13 \mathrm{kDa}$. The acidic character of these proteins, designated A-proteins, is the result of very high (18\%) glutamic acid content. A-proteins contain only a few aromatic residues, one or two arginines and about $20 \%$ of alanine. Eucaryotic A-proteins are related in structure and function to procaryotic ribosomal proteins L7/L12 and are involved in the interaction of translation factors (elongation factor 2) with ribosomes during translation of the genetic message (reviewed in [1, 2]). A-Proteins belong to a group of so called "exchangeable" proteins, i.e. they cycle in vivo between ribosome particles and cytoplasm [ $3-5]$. It is interesting that ribosome-bound acidic proteins but not cyto- plasmic ones, are modified by phosphorylation $[6,7]$.

In S. cerevisiae ${ }^{1}$ four members of the A-protein family, encoded by four independent genes, have been identified. According to the recent unifying nomenclature [8] they are called YP1 $\alpha$, YP1 $\beta, Y P 2 \alpha$ and YP2 $\beta$. The latter three proteins, previously called L44', L44 and L45, were purified and chemically characterized [9, $10]$. The yeast acidic proteins can be grouped in two pairs, YP1 $\alpha / Y \mathrm{P} 1 \beta\left(\mathrm{L} 44^{\prime}\right)$ and YP2 $\alpha(\mathrm{L} 44) /$ /YP2 $\beta$ (L45), which seem to play a complementary role in ribosome function [11].

In $S$. pombe, which are morphologically and physiologically distinct from the budding yeast S. cerevisiae, four genes (RPA1-4) for A-proteins were cloned. They can be divided in two pairs of very similar but not identical sequences,

\footnotetext{
*This work was supported by a research grant from the State Committee for Scientific Research No. 4-0354/9101.

${ }^{1}$ Abbreviations: CKI, casein kinase I; CKII, casein kinase II; PK60S, protein kinase phosphorylating A-proteins of 605 ribosomal subunit; S. cerevisiae, Saccharomyces cerevisiae; S. pombe, Schizosaccharomyces pombe; $\mathrm{PMSF}$, phenylmethylsulfonyl fluoride; $\mathrm{YP}$, yeast (S. cerevisiae) acidic ribosomal proteins.
} 
RPA1/RPA3 and RPA2/RPA4. It was shown by genetic analysis that one gene of each pair (RPA3 and RPA4) is essential for cell growth whereas RPA1 and RPA2 are not [12].

It is known that eucaryotic A-proteins are phosphorylated by multifunctional casein kinase II (CKII) [13 - 16]. Recently a new protein kinase, with high substrate specificity for Aproteins, was isolated from cytoplasm of $S$. cerevisiae [15]. We report here a comparative analysis of phosphorylation in vitro by protein kinase tightly associated with ribosomes, of A-proteins from S. cerevisiae and S. pombe.

\section{METHODS}

Preparation of yeast cell-free extracts and ribosomes. S. cerevisiae, strain SKQ2N (C.S. McLaughlin, California University, Irvine, U.S.A.) and S. pombe strain $927 \mathrm{~h}^{-}$(P. Nurse, Department of Biochemistry, Oxford, U.K.) were cultivated under aerobic conditions in YEP medium (yeast extract, peptone, glucose) at $28^{\circ} \mathrm{C}$. When required, cells were grown in the phosphate-free medium of Retel \& Planta [17] in the presence of $10 \mu \mathrm{Ci} / \mathrm{ml}(1 \mathrm{Ci}=37 \mathrm{MBq})$ of carrier free ${ }^{32} \mathrm{PO}_{4}{ }^{3-}$. The cell-free extracts were prepared in buffer $\mathrm{A}(50 \mathrm{mM}$ Tris $/ \mathrm{HCl}, \mathrm{pH} 7.5$, $10 \mathrm{mM} \mathrm{Mg}\left(\mathrm{CH}_{3} \mathrm{COO}\right)_{2}, 10 \mathrm{mM} \mathrm{KCl}, 10 \mathrm{mM}$ 2-mercaptoethanol, $1 \mathrm{mM}$ PMSF) according to procedure described [18]. Ribosomes were separated from postmitochondrial supernatant by centrifugation at $100000 \times g$ for $2.5 \mathrm{~h}$. Crude ribosomal pellet was suspended in buffer $A$ containing $1 \%$ Triton $X-100$, stirred for $1 \mathrm{~h}$ and centrifuged as described earlier [18]. Triton X100 washed ribosomes were resuspended in buffer A containing $0.5 \mathrm{M} \mathrm{KCl}$ and sedimented in the conditions described before. Salt washed ribosomes were resuspended in buffer A containing $0.5 \mathrm{M} \mathrm{KCl}$ and sedimented through a cushion of $1 \mathrm{M}$ sucrose in the same buffer. Ribosomes collected at the consecutive steps of the purification were used as phosphorylation substrates. All ribosomal preparations were stored in $40 \%$ glycerol in buffer A at $-20^{\circ} \mathrm{C}$.

Protein kinase assay. The standard reaction mixture contained in a total volume of $50 \mu 150$ $\mathrm{mM}$ Tris/ $\mathrm{HCl}$, pH 7.5; $10 \mathrm{mM} \mathrm{Mg}\left(\mathrm{CH}_{3} \mathrm{COO}\right)_{2}$, $1 \mathrm{mM}$ DTT, 100 - $150 \mu \mathrm{g}$ ribosomes or another substrate indicated in the text, varying amounts of kinase preparations and $0.03 \mathrm{mM}$ $\left[\gamma^{32}\right.$ P]ATP (1000 c.p.m./pmol). The mixture was incubated at $30^{\circ} \mathrm{C}$ for $30 \mathrm{~min}$. The reaction was stopped by the addition of $50 \mu 110 \%$ trichloroacetic acid and the samples were boiled in a water bath for $15 \mathrm{~min}$. The radioactivity retained in acid insoluble material was determined by liquid scintillation spectrometry.

For SDS-polyacrylamide gel electrophoresis, the reactions were stopped by the addition of $25 \mu l$ sample buffer [19] to the incubation mixture. For phosphorylation in situ $100-150 \mu \mathrm{g}$ ribosomes were used as both an enzyme and a substrate source.

Preparation of acidic ribosomal proteins. The acidic proteins were extracted from the ribosomes $(20 \mathrm{mg} / \mathrm{ml})$ by washing with $0.25 \mathrm{M}$ $\mathrm{NH}_{4} \mathrm{Cl} / 50 \%$ ethanol at $0^{\circ} \mathrm{C}$ for $20 \mathrm{~min}$ as described by Sanchez-Madrid et al. [20]. The core particles were sedimented by centrifugation at $12000 \times g$ for $15 \mathrm{~min}$. The split protein fractions (SP0.25) containing mainly the acidic ribosomal proteins, were precipitated by the addition of 3 vol. of acetone at $-20^{\circ} \mathrm{C}$.

Electrophoretic methods. Electrophoresis in SDS/12\% polyacrylamide $(w / v)$ slab gels (SDS-PAGE) was performed according to Laemmli [19]. Gels were stained in Coomassie Brilliant Blue R-250.

The relative molecular mass of proteins were calculated on the basis of the following marker proteins (Sigma): phosphorylase b (94000), bovine serum albumin (68000), ovalbumin (43000), carbonic anhydrase ( 30000$)$, soybean trypsin inhibitor (20100) and $\alpha$-lactalbumin (14400).

Isoelectric focusing of acidic proteins was performed in $5 \%$ polyacrylamide $(w / v)$ slab gels with $6 \mathrm{M}$ urea and $2 \%$ LKB ampholines in the 2.5 to $5 \mathrm{pH}$ range [9]. Proteins were detected by silver staining [21]. Radioactive phosphopeptides were detected by autoradiography.

Isolation and partial purification of ribosome-associated protein kinases. Yeast Triton $\mathrm{X}-100$ washed ribosomes were used as a source of ribosome associated protein kinases. Ribosomal pellets were resuspended in buffer $A$ containing $1 \mathrm{M} \mathrm{KCl}$ and $50 \mathrm{mM} \mathrm{Mg}\left(\mathrm{CH}_{3} \mathrm{COO}\right)_{2}$ and stirred for $1 \mathrm{~h}$. Thereafter the ribosomes were sedimented from the solution and the supernatant was thoroughly dialysed in buffer B (50 mM Tris/ $\mathrm{HCl}, \mathrm{pH} 7.5,0.5 \mathrm{mM}$ EDTA, 10 $\mathrm{mM}$ 2-mercaptoethanol and $1 \mathrm{mM}$ PMSF). 
The dialysed ribosomal extract was loaded on DEAE-cellulose (DE-52 Whatman) equilibrated with buffer $B$. Proteins were eluted with $250 \mathrm{ml}$ linear $\mathrm{NaCl}$ gradient $(0-0.4 \mathrm{M})$ in buffer B. Each second fraction $(10 \mu \mathrm{l})$ was tested for protein kinase activity using casein or purified 805 ribosomes as phosphorylation substrate. CKII bound to the DEAE-cellulose under described conditions was eluted at $0.25 \mathrm{M} \mathrm{NaCl}$. The flow-through fractions containing both casein and the ribosome phosphorylating activity was subsequently loaded on phosphocellulose (P-11 Whatman) column equilibrated with buffer B. Proteins were eluted with $100 \mathrm{ml}$ of linear $\mathrm{NaCl}(0-0.7 \mathrm{M})$ gradient. Aliquots of 10 $\mu l$ were assayed for protein kinase activity using casein or ribosomes as phosphorylating substrates.

Fractions active in ribosomal A-protein phosphorylation were pooled, concentrated and dialysed against buffer $B$. They were stored in $40 \%$ glycerol at $-20^{\circ} \mathrm{C}$.

Glycerol gradient analysis. Ribosomal protein kinase $(200 \mu \mathrm{l})$ obtained after DEAE-cellulose chromatography was loaded on the linear glycerol gradient $(10 \%-30 \%)$ in buffer A. Samples were centrifuged for $17 \mathrm{~h}$ at 45000 r.p.m. at $4^{\circ} \mathrm{C}$ in Beckman SW 65 rotor. Samples of $250 \mu \mathrm{l}$ were collected. Aliquots of $20 \mu \mathrm{l}$ were assayed for protein kinase activity. Ribosomal proteinphosphorylation level was analysed by SDS-

\section{S. cerevisiae}

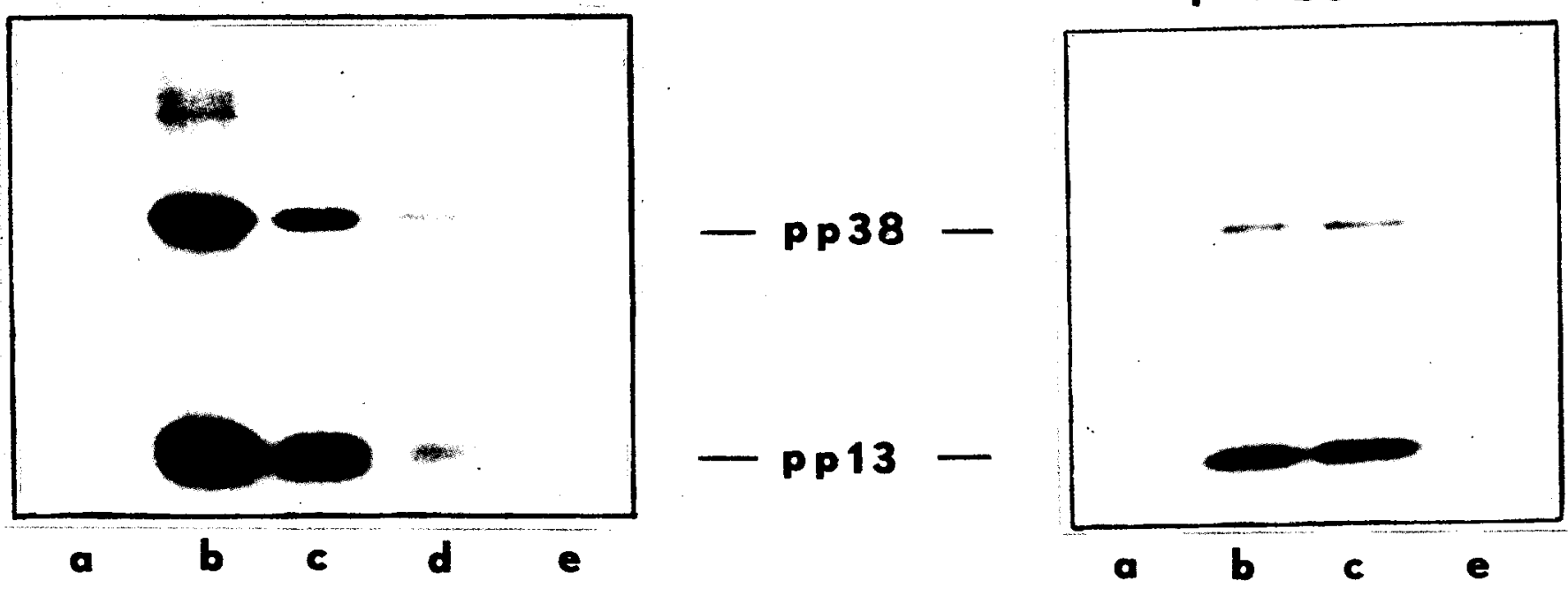

Fig. 1. Endogenous phosphorylation of ribosomal proteins from S. cerevisiae and S. pombe by ribosome associated protein kinase.

Ribosomes $(75 \mu \mathrm{g})$ collected at consecutive steps of purification were incubated with $\left[\gamma^{32} \mathrm{P}\right] \mathrm{ATP}$ under standard conditions and subjected of SDS-PAGE and autoradiography for $24 \mathrm{~h}$. Lanes: a, crude ribosomes; $b$, Triton X-100 washed ribosomes; c, ribosomes washed with buffered solution of $0.5 \mathrm{M} / \mathrm{KCl}$; d, ribosomes washed twice with $0.5 \mathrm{M} \mathrm{KCl}$; ribosomes washed twice with $0.5 \mathrm{M} \mathrm{KCl}$ and sedimented through $1 \mathrm{M}$ sucrose. radiography.

\section{RESULTS}

Endogenous phosphorylation of ribosomal proteins by protein kinase activities associated with

To study phosphorylation in situ of the acidic proteins of $80 \mathrm{~S}$ ribosomes from $S$. cerevisiae, ribosomes were collected at the consecutive steps of the purification procedure and incubated with $\left[\gamma_{-}^{32}\right.$ P]ATP in the absence of exogenous protein kinases. ${ }^{32} \mathrm{P}$-Labelled proteins were analysed by SDS-polyacrylamide gel electrophoresis and then detected by autoradiography. Two radioactive bands of $M_{\mathrm{r}} 13000$ and 38000 were identified (Fig. 1). Significant quantitative differences in protein phosphorylation between the analysed ribosome preparations were observed. Incorporation of $\left[{ }^{32} \mathrm{P}\right]$ phosphate was very low in the case of crude ribosomes (Fig. 1, line a). It increased significantly after treatment of crude ribosomes with $1 \%$ Triton X-100 (Fig. 1, line b). This protein kinase activity was not completely removed by washing of ribosomes with a buffer containing $0.5 \mathrm{M} \mathrm{KCl}$ but considerably diminished (Fig. 1, line c). A second wash in high salt buffer and centrifugation through a

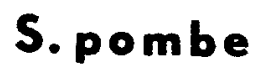

polyacrylamide gel electrophoresis and autoyeast ribosomes 
cushion of $1 \mathrm{M}$ sucrose removed most of the residual activity (Fig. 1, line d, e).

Ultracentrifugation analysis carried out under conditions promoting dissociation of $80 \mathrm{~S}$ ribosomes, proved that both endogenously phosphorylated proteins belong to 605 ribosomal subunits (not shown).

A parallel study was performed on the phosphorylation of acidic proteins of 805 ribosomes from fission yeast $S$. pombe (Fig. 1B). Similarly as in S. cerevisiae, two radioactive protein bands of $M_{\mathrm{r}} 13000$ and 38000 were detected by autoradiography. Like in the budding yeast, the highest phosphorylation level was observed in the case of Triton X-100 treated ribosomes of $S$. pombe (Fig. 1, line b).

A-Proteins phosphorylated in situ extracted from $S$. cerevisiae and $S$. pombe ribosomes by $50 \%(\mathrm{v} / \mathrm{v})$ ethanol and $0.25 \mathrm{M} \mathrm{NH}_{4} \mathrm{Cl}$ washes (SP0.25 fractions) on one dimensional SDS-gel electrophoresis revealed the presence of a major protein band with relative molecular mass of 13000 . By using isoelectric focusing that protein band was resolved into several forms differing in charge over the acidic $\mathrm{pH}$ range. In S. cerevisiae three and in S. pombe four major radioactive forms of A-proteins ${ }^{32} \mathrm{P}$-labelled either in vivo (Fig. 2, line b) or in vitro (Fig. 2, line c) were detected. They correspond to YP2 $\alpha-(\mathrm{L} 44), \mathrm{YP} 1 \beta\left(\mathrm{L} 44^{\prime}\right)$ and YP2 $\beta$ (L45) and tentatively designated proteins to $A 1, A 2, A 3$ and $\mathrm{A} 4$, respectively. The $38 \mathrm{kDa}$ ribosomal phosphoprotein observed in SDS-polyacrylamide gels (Fig. 1) in both yeast species studied was not present in $\mathrm{SP}_{0.25}$ fractions and remained bound to the ribosomal core particles. That protein was first discovered in S. cerevisiae and identified as an AO protein by Mitsui et al. [22].
Endogenous phosphorylation of A-proteins of $80 \mathrm{~S}$ ribosomes in the presence of CKII effectors

The obtained results clearly point to the existence of protein kinase activity tightly associated with the ribosomes of both yeast species studied.

It is known from the earlier studies that casein kinase II is tightly associated with $80 \mathrm{~S}$ ribosomes of many eucaryotic organisms [23 - 27]. The activity of CKII is inhibited by low concentrations of heparin or poly(L-glutamyl) peptides, and is stimulated by aliphatic polyamines. The enzyme can utilize both ATP and GTP as phosphate donors [28, 29].

The activity of ribosome-associated protein kinase from $S$. cerevisiae was examined in the presence of CKII effectors (Fig. 3). The phosphorylation of ribosomal proteins of $38 \mathrm{kDa}$ and $13 \mathrm{kDa}$ was significantly reduced in the presence of increasing amounts of heparin (Fig. 3 , line b, c, d). An excess of GTP also decreased the phosphorylation level of either protein (Fig. 3 , line $f$ ) while in the presence of spermin increased phosphorylation was observed (Fig. 3, line e). All the data obtained indicate the presence of CKII activity associated with $S$. cerevisiae ribosomes. Similar results were obtained in the case of $S$. pombe (not shown).

\section{Isolation and characterization of ribosome-asso- ciated protein $k$ inases}

The existence of casein kinase II associated with yeast ribosomes was confirmed by fractionation on DEAE-cellulose of the $1 \mathrm{M} \mathrm{KCl}$ ribosomal wash: CKII bound to the resin was eluted at about $0.25 \mathrm{M} \mathrm{NaCl}$ concentration (Fig. 4A). By using one dimensional SDS-polyacrylamide gel electrophoresis it was confirmed that
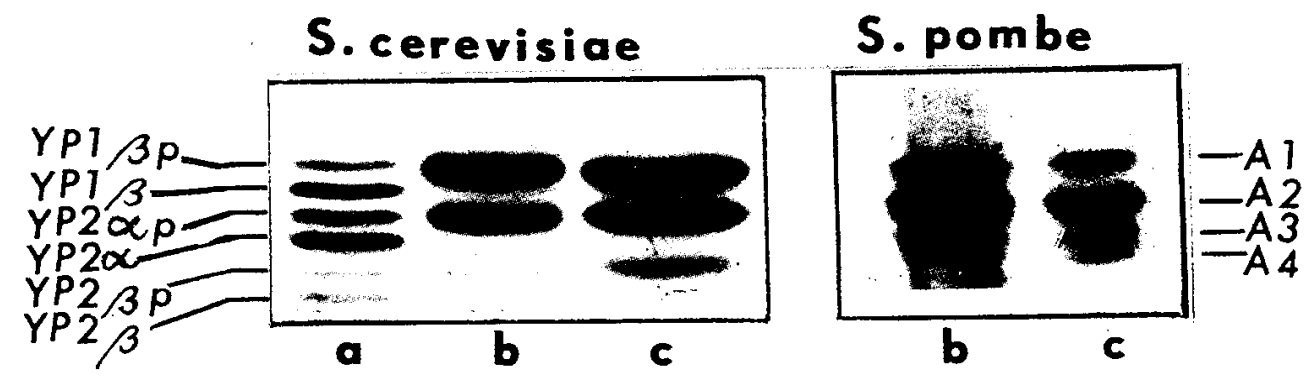

Fig. 2. Separation of acidic ribosomal proteins from S. cerevisiae (A) and S. pombe (B) by isoelectrofocusing. The acidic proteins were extracted from $1 \mathrm{mg}$ of Triton $\mathrm{X}-100$ washed ribosomes by $0.25 \mathrm{M} \mathrm{NH} / \mathrm{Cl} / 50 \%$ ethanol after labelling in vitro with $\gamma^{32} \mathrm{P}$ (line $\mathrm{c}$ ) or after labelling of yeast cells in vivo with $10 \mu \mathrm{Ci} / \mathrm{ml} \mathrm{[}{ }^{32} \mathrm{P}$ ]phosphate for $3 \mathrm{~h}$ (line b). Proteins were detected by silver staining (line a) and autoradiography (lineb, $c$ ). The positions of phosphorylated (marked with a "p") and unphosphorylated forms of different proteins are indicated. 


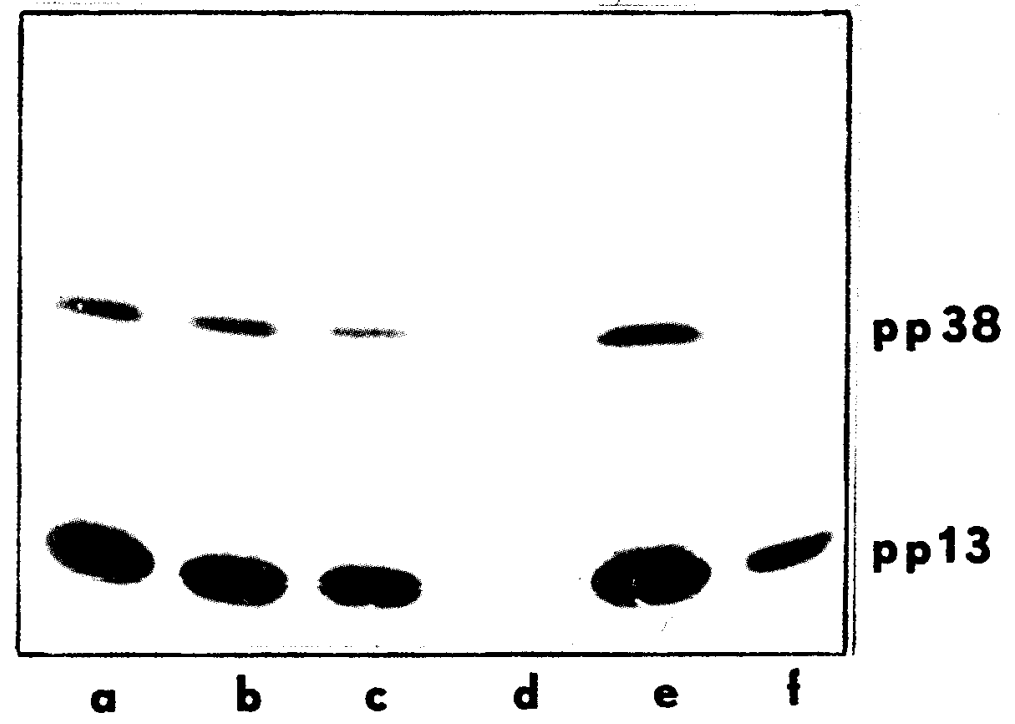

Fig. 3. Endogenous phosphorylation of ribosomal proteins from S. cereoisiae in the presence of casein kinase Il effectors.

Triton X-100 washed ribosomes were used as an enzyme and a substrate source. Ribosomes $(75 \mu \mathrm{g})$ were incubated with $\left[\gamma_{-}{ }^{32}\right.$ P]ATP under standard conditions and analyzed by SDS-PAGE and autoradiography. Lines: $a$, control; $b$, heparin $(1 \mu \mathrm{g} / \mathrm{ml}) ;$ c, heparin $(10 \mu \mathrm{g} / \mathrm{ml}) ; \mathrm{d}$, heparin $(50 \mu \mathrm{g} / \mathrm{ml}) ; \mathrm{e}$, spermin $(0.2 \mathrm{mM}) ; \mathrm{f}, \mathrm{GTP}(0.3 \mathrm{mM})$.

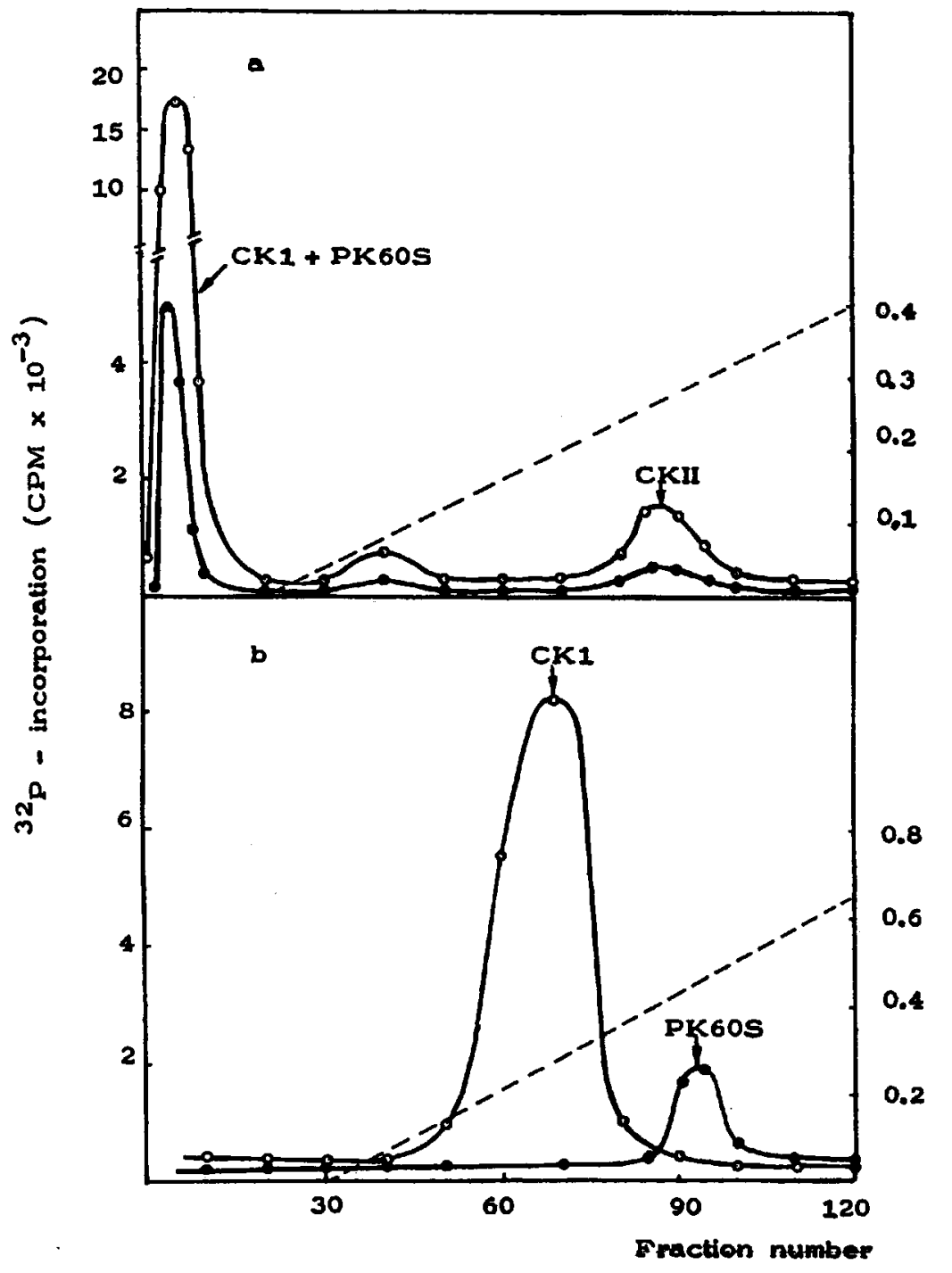

Fig. 4. Chromatography of ribosomal wash of $S$. cerevisiae on DEAE-cellulose and phosphocellulose.

The protein was extracted from Triton X-100 washed ribosomes with buffered solution of $1 \mathrm{M}$ $\mathrm{KCl}$ and loaded on DEAEcellulose (A). The flow-through fraction was subsequently fractionated on phosphocellulose (B) under conditions described in Methods section. Aliquots of $10 \mu \mathrm{l}$ of selected fractions were assayed for protein kinase activity using casein $(0)$ or purified $80 S$ ribosomes $(\Theta)$ as phosphorylation substrates. 
the isolated CKII fraction can use acidic $38 \mathrm{kDa}$ and $13 \mathrm{kDa}$ ribosomal proteins as phosphorylation substrates (Fig. 5, line c).

It can also be seen from Fig. 4 that the flowthrough fractions from the DEAE-cellulose column contained protein kinase activities which phosphorylated both casein and A-proteins. Phosphocellulose chromatography, used as the next step of purification, was particularly useful in resolving the two activities. The casein phosphorylating activity, identified as CKI, was eluted from the resin at $0.35 \mathrm{M} \mathrm{NaCl}$ concentration. The protein kinase which phosphorylated A-proteins was eluted at $0.5 \mathrm{M} \mathrm{NaCl}$ (Fig. 4B).

Sedimentation of the native form of the latter enzyme on the glycerol gradient (10\% - 30\%) was compared with that of protein standards of known molecular mass. The enzyme activity was detected in the same fractions as bovine serum albumin used as a marker $(68 \mathrm{kDa}$; Fig. 6).

The presented data and other not included in this paper, indicate that the enzyme isolated from ribosomes is the specific protein kinase phosphorylating $60 \mathrm{~S}$ ribosomal proteins, simi-

lar as that purified recently from the S. cerevisiae postribosomal supernatant [15].

DEAE-cellulose chromatography was also used for fractionation of ribosomal wash from S. pombe. Both casein kinase activities: CKI and CKII were identified in the fractions. However, the activity phosphorylating A-protein was not detected in the flow-through fractions (Fig. 5, line b).

\section{DISCUSSION}

Most of the acidic proteins of the 605 ribosomal subunit play a very important role in the regulation of ribosomal activity. It was reported that the amount of A-proteins found in the ribosomes depends on the active state of this particles [3], Thus, ribosomes from exponentially growing cells have almost twice as many of these polypeptides as ribosomes from the stationary phase cultures; similarly, particles in polysomes contain more acidic proteins than free ribosomes [30]. The affinity of A-proteins for the ribosomes depends on their phosphorylation state. Only ribosome-bound A-proteins become phosphorylated. The un-
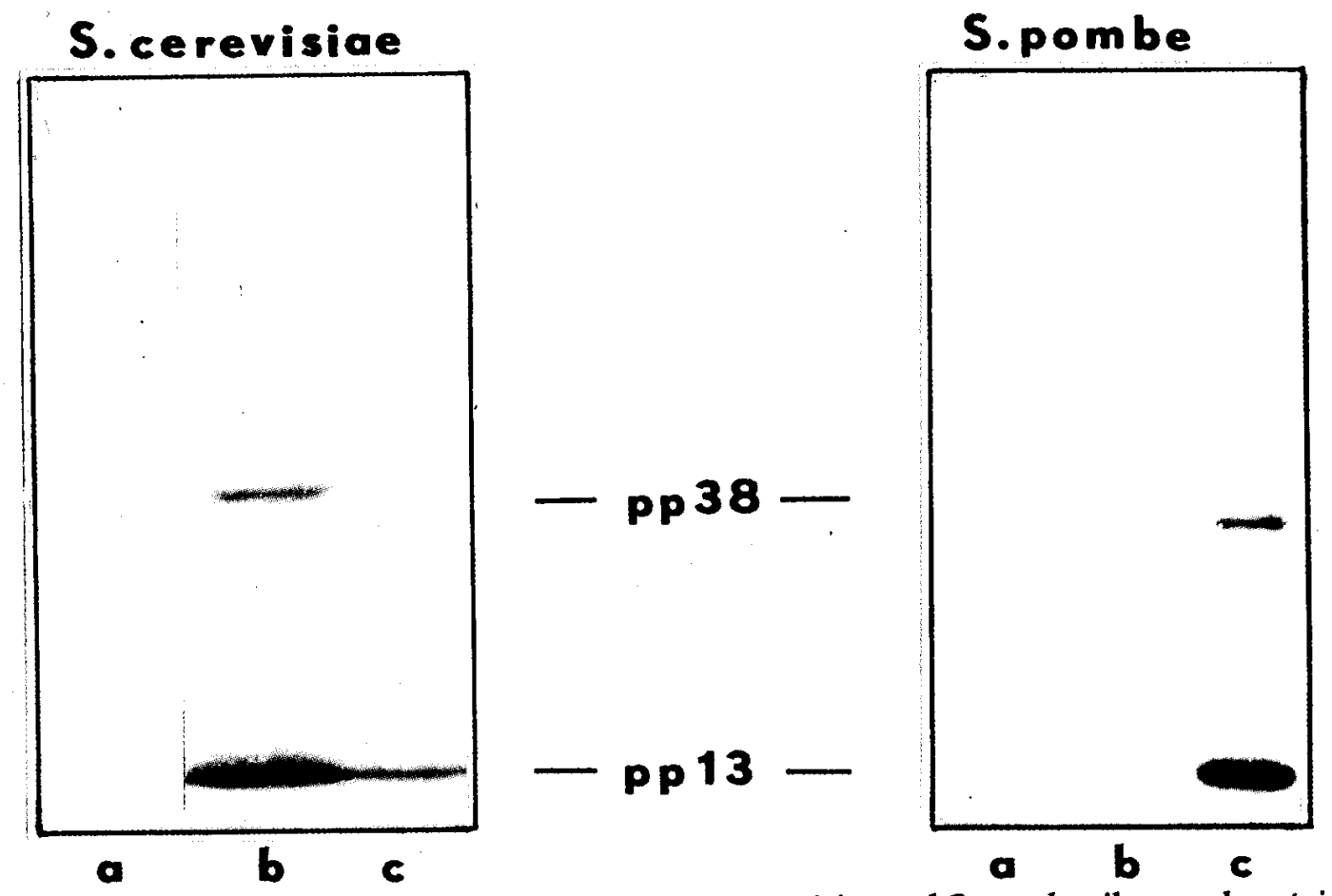

Fig. 5. Phosphorylation of acidic ribosomal proteins by S. cerevisiae and S. pombe ribosomal protein kinases after fractionation on DEAE-cellulose.

Aliquots of $10 \mu \mathrm{l}$ of selected fractions were assayed for protein kinase activity using purified 80S ribosomes as phosphorylation substrates. Phosphorylated proteins were identified by SDS-PAGE and autoradiography. Ribosomes were incubated with: line $a$, no addition; line $b$, flow-through fraction after DEAE cellulose; line $c$, fraction eluted with $250 \mathrm{mM} \mathrm{NaCl}$ (CKII). 


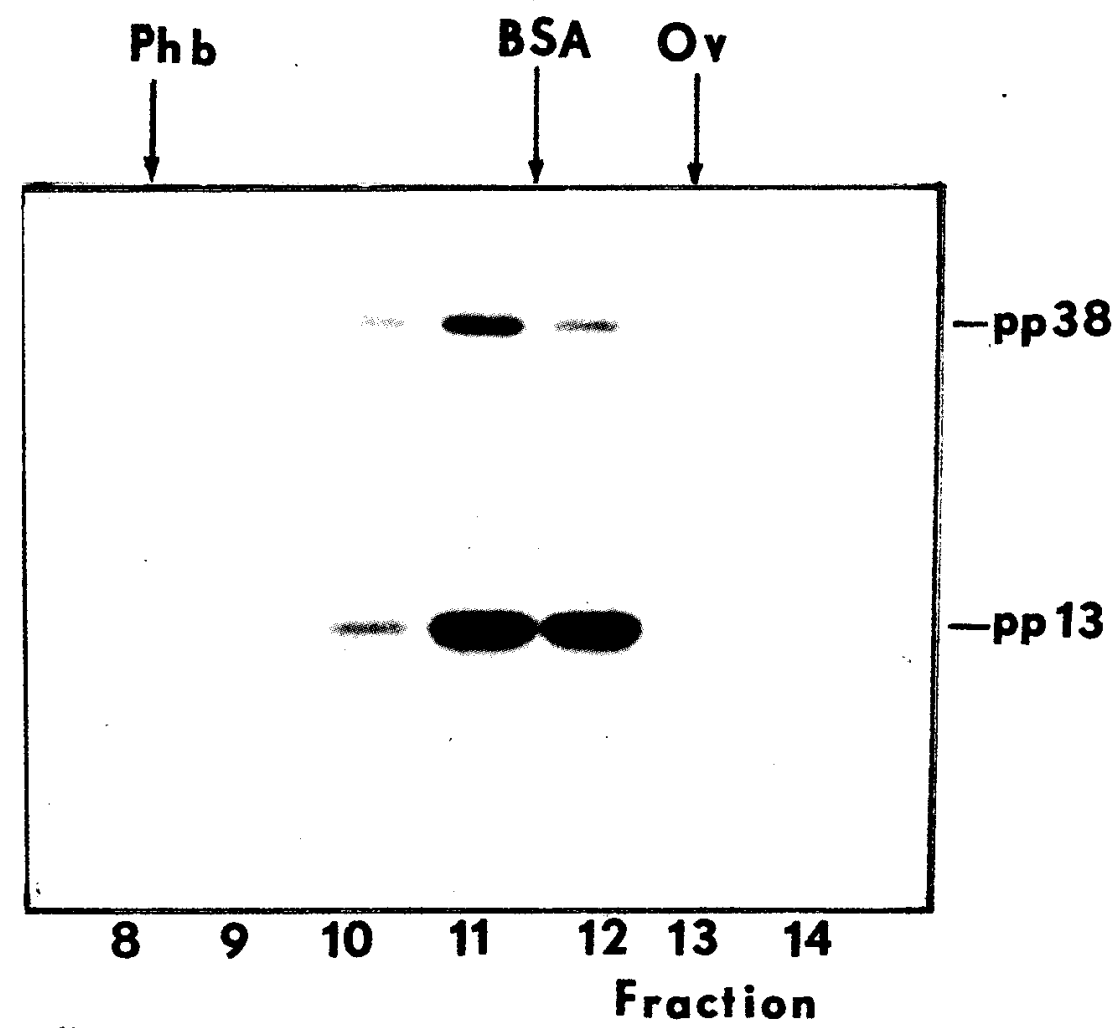

Fig. 6. Glycerol gradient centrifugation of ribosome-associated protein kinase from S. cerevisiae.

The ribosomal protein kinase flow-through fraction $(200 \mu \mathrm{l})$ after DEAE-cellulose chromatography, was subjected to linear (10 - 30\%) glycerol gradient centrifugation under standard conditions. Aliquots of $20 \mu \mathrm{l}$ of the collected fractions were assayed for protein kinase activity using purified $80 \mathrm{~S}$ ribosomes as a phosphorylation substrate. Ribosomal protein phosphorylation was analysed by SDS-PAGE and autoradiography. Positions of molecular mass standards are indicated by arrows. Phb, phosphorylase b (94 kDa); BSA, bovine serum albumin ( $68 \mathrm{kDa})$; OV, ovalbumin (43 kDa).

usually large pool of these ribosomal proteins which are present in the cytoplasm, are in the unphosphorylated state [5, 6]. It is possible that under different physiological conditions changes in either specific A-protein kinase or phosphatase activities can control the amount of these proteins bound to the ribosomal particles. One might propose that ribosomal A-proteins can be phosphorylated by the ribosome-associated protein kinases. In this paper we describe the identification and partial characterization of protein kinase activities tightly associated with ribosomes from two distantly related yeast species $S$. cerevisiae and S. pombe.

The ribosome-associated kinase activity can be released by extensive washing in a high salt buffer or after dissociation of ribosomes into $40 S$ and 605 subunits. It is interesting that the endogenous phosphorylating activity is much lower in the crude preparation of ribosomes than in the Triton X-100 washed ones. It could be speculated that treatment with low concentration of detergent may increase the phosphorylation level of A-proteins by changing the conformation of the substrates and, as a consequence, by increasing the access of the substrates to the enzyme. However, the addition of Triton X-100 to the incubation mixture containing crude ribosomes did not stimulate the activity.

From our preliminary observations it can be tentatively concluded that Triton X-100 treatment released "an inhibitory fraction" from the crude preparation of ribosome.

In various eucaryotic organisms, multifunctional casein kinase II is known to be associated with ribosomes. The results of our experiments clearly indicate that CKII is also tightly associated with ribosomes of the two yeast species studied.

It seems of interest that, in the ribosome preparation of $S$. cerevisiae, besides CKII another protein kinase phosphorylating A-proteins was detected. This enzyme showed very high substrate specificity toward $13 \mathrm{kDa}$ and $38 \mathrm{kDa}$ proteins of 605 ribosomal subunits. An enzyme with similar properties, designated 605 protein kinase (PK60S), was recently discovered in the $S$. cerevisiae postribosomal supernatant [15]. It 
is known from unpublished observations Grankowski et al. (personal communication), that both CKII and PK60S phosphorylate the same sites in $38 \mathrm{kDa}$ and $13 \mathrm{kDa}$ proteins. The existence of two different protein kinases phosphorylating the same specific sites in the same substrates poses the question about the role of both enzymes in phosphorylation in vivo. It can not be excluded that this two enzymes differ in specificity toward individual A-proteins: YP1 $\beta$, YP2 $\alpha$ and YP2 $\beta$ in the cell.

Multicellular organisms (a crustacea, an insect and a vertebrate) have been shown to contain two small A-proteins whereas in the budding yeast $S$. cerevisiae four distinct proteins were identified [31]. Four A-proteins were recently characterized in Dictyostelium discoideum [16]. It was also reported that the fission yeast $S$. pombe contain four individual genes (RPA14) for A-proteins [12], confirming the suggestion that this might be a characteristic feature of lower eucaryotes.

By genetic analysis it was demonstrated, that two of these genes, RPA3 and RPA4, were essential for cell survival [12]. By using isoelectric focusing of the $\mathrm{SP}_{0.25}$ fraction of ribosomes phosphorylated in situ, four different phosphoproteins were now identified. However, these data do not allow us to distinguish conclusively whether these proteins are multiphosphorylated forms of a single polypeptide or monophosphorylated forms of four individual proteins. On the basis of cDNA sequence analysis, the amino-acid sequence of A-proteins was predicted [12]. At the proximal C-terminal end of all four proteins, the cluster of acidic residues located on both sides of serine residue can be identified (EESDED) [12]. It is the specific recognition site of phosphorylation for CKII $[32,33]$. None of other serines are surrounded by such a cluster of acidic residues. This may indicate that the four phosphoprotein bands observed in our experiments represent monophosphorylated products of the individual genes. However, the protein designated A2, is sometimes seen in our isoelectrofocusing gels as a double band. Further study, now in progress, is required to elucidate this problem.

We would like to thank Miss K. Rusinek for her secretarial assistance.

\section{REFERENCES}

1. Bielka, H. (1982) The eukaryotic ribosome. Springer-Verlag K.G., Berlin.

2. Moller, W. \& Maassen, A.J. (1986) On the structure, function and dynamics of L7/L12 from Escherichia coli ribosomes; in Structure, Function and Genetics of Ribosomes (Hardesty, B. \& Kramer, G., eds.) pp. 309 - 325, SpringerVerlag, New York.

3. Mitsui, K., Nakagawa, T. \& Tsurugi, K. (1988) On the size and the role of a free cytosolic pool of acidic ribosomal proteins in yeast Saccharomyces cereoisiae. J. Biochem. 104, 908-911.

4. Zinker, S. \& Warner, J.R. (1976) The ribosomal protein of Saccharomyces cerevisiae. Phosphorylated and exchangeable proteins. J. Biol. Chem. 251, 1799 - 1807.

5. Zinker, S. (1980) $\mathrm{P} 5 / \mathrm{P}^{\prime}$ the acidic ribosomal phosphoproteins from Saccharomyces cerevisiae. Biochim. Biophys. Acta 606, 76 - 82.

6. Sanchez-Madrid, F., Juan-Vidales, F. \& Ballesta, J.P.G. (1981) Effect of phosphorylation on the affinity of acidic proteins from Saccharomyces cerevisiae for the ribosome. Eur. J. Biochem. 114, $609-613$.

7. Naranda, T. \& Ballesta, J.P.G. (1991) Phosphorylation controls binding of acidic proteins to the ribosome. Proc. Natl. Acad. Sci. U.S.A. 88, 10563 - 10567.

8. Wool, I.G., Chan, Y.L., Gluck, A. \& Suzuki, K. (1991) The primary structure of rat ribosomal proteins P0, P1 and P2 and a proposal of a uniform nomenclature for mammalian and yeast ribosomal proteins. Biochimie 73, 861 - 870.

9. Juan-Vidales, F., Saenz-Roblez, M.T. \& Ballesta, J.P.G. (1984) Acidic proteins of the large ribosomal subunit in Saccharomyces cerevisiae. Effect of phosphorylation. Biochemistry 23, 390 396.

10. Vilella, M.D., Remacha, M., Ortiz, B.L., Mendez, E. \& Ballesta, J.P.G. (1991) Characterization of the yeast acidic ribosomal phosphoproteins using monoclonal antibodies. Eur. J. Biochem. 196, 407 - 414.

11. Remacha, M., Santoz, C. \& Ballesta, J.P.G. (1990) Disruption of single-copy genes encoding acidic ribosomal proteins in Saccharomyces cerevisiae. Mol. Cell. Biol. 10, 2182 - 2190.

12. Beltrame, M. \& Bianchi, M.E. (1990) A gene family for acidic ribosomal proteins in Schizosaccharomyces pombe: Two essential and two 
nonessential genes. Mol. Cell. Biol. 10, 2341 2348.

13. Leader, D.P. \& Coia, A.A. (1977) The phosphorylation of an acidic protein of the large ribosomal subunit of Krebs II ascites cells. Biochem. J. 162, 199 - 200.

14. Meggio, F., Brunati, A.M., Donella-Deana, A. \& Pinna, L. (1984) Detection of type 2 casein kinase and its endogenous substrates in the components of the microsomal fraction of rat liver. Eur. J. Biochem. 138, 379 - 385.

15. Pilecki, M., Grankowski, N., Jacobs, J. \& Gasior, E. (1992) Specific protein kinase from Saccharomyces cerevisiae cells phosphorylating $60 \mathrm{~S}$ ribosomal proteins. Eur. J. Biochem. 206, 259-267.

16. Prieto, J., Candel, E., Fernandez-Renart, M. \& Coloma, A. (1991) Dictyostelium discoideum acidic ribosomal phosphoproteins: Identification and in vivo phosphorylation. Biochim. Biophys. Acta 1115, 6 - 14.

17. Retel, J. \& Planta, R.J. (1967) Ribosomal precursor RNA in Saccharomyces carlsbergensis. Eur. J. Biochem. 3, 248 - 258.

18. Grankowski, N., Kudlicki, W., Paleń, E. \& Gasior, E. (1976) Proteins of yeast ribosomal subunits: number and general properties. Acta Biochim. Polon. 23, 341 - 352.

19. Laemmli, U.K. (1970) Cleavage of structural proteins during the assembly of the head of bacteriophage T4. Nature (London) 227, 680-685.

20. Sanchez-Madrid, F., Reyes, R., Conde, P. \& Ballesta, J. P.G. (1979) Acidic ribosomal proteins from eucaryotic cells. Effect on ribosomal functions. Eur. J. Biochem. 98, 409 - 416.

21. Oakley, B.R., Kirsch, D.R. \& Morris, N.R. (1980) A simplified ultrasensitive silver stain for detecting proteins in polyacrylamide gels. Anal. Biochem. 105, 361 - 363.

22. Mitsui, K., Motizuki, M., Endo, J., Yokota, S. \& Tsurugi, K. (1987) Characterization of a novel acidic protein of $38 \mathrm{kDa}, \mathrm{AO}$, in yeast ribosomes which immunologically cross-react with the 13 $\mathrm{kDa}$ acidic ribosomal proteins, $\mathrm{A} 1 / \mathrm{A} 2$. I. Biochem. 102, 1565 - 1570.

23. Thoen, C., De Herdt, E. \& Slegers, H. (1986) Identification of the ribosomal proteins phosphorylated by the ribosome-associated casein kinase type II from cryptobiotic gastrulae of the brine shrimp Artemia sp. Biochem. Biophys. Res. Commun. 135, 347 - 354.

24. Thoen, C. \& Slegers, H. (1985) Ribosome associated cyclic nucleotide-independent protein kinase of Artemia salina cryptobiotic gastrulae. Biochim. Biophys. Acta 825, 268 - 279.
25. Grankowski, N., Kudlicki, W. \& Gąsior, E. (1974) Ribosome associated protein kinase from Saccharomyces cerevisiae. FEBS Lett. 47, 103 - 106.

26. Issinger, O.G. (1977) Phosphorylation of acidic ribosomal proteins from rabbit reticulocytes by a ribosome-associated casein kinase. Biochim. Biophys. Acta 477, 185 - 189.

27. Nuntinen, M. \& Londonsborough, J. (1988) The stimulation of a casein kinase II from yeast by polyamines occurs with endogenous substrates at cytosolic salt levels. Second Messengers and Phosphoproteins 12, 197 - 205.

28. Hathaway, G.M. \& Traugh, J.A. (1982) Casein kinases-multipotential protein kinases. Current Topics in Cellular Regulation 21, 102 - 124.

29. Meggio, F., Grankowski, N., Kudlicki, W., Szyszka, R., Gąsior, E. \& Pinna, L.A. (1986) Structure and properties of casein kinase II from Saccharomyces cerevisiae. A comparison with the liver enzyme. Eur. J. Biochem. 159, 31 - 38.

30. Saenz-Robles, M.T., Remacha, M., Vilella, M.D., Zinker, S. \& Ballesta, J.P.G. (1990) The acidic ribosomal proteins as regulators of the eukaryotic ribosomal activity. Biochim. Biophys. Acta 1050, 51 - 55.

31. Mitsui, K. \& Tsurugi, K. (1989) Identification of A1 protein as the fourth member of $13 \mathrm{kDa}$-type acidic ribosomal protein family in yeast Saccharomyces cerevisiae. Biochem. Biophys. Res. Commun. 161, 1001 - 1006.

32. Kemp, B.E. \& Pearson, R.B. (1990) Protein kinase recognition sequence motifs. Trends Biochem. Sci. 15, 342 - 346.

33. Kenelly, P.J. \& Krebs, E.G. (1991) Consensus sequences as substrate specificity determinants for protein kinases and protein phosphatases. J. Biol. Chem. 266, 15555 - 15558. 